\section{The management of the surgical complications of HELLP syndrome}

\author{
SG Wilson*, AD White*, AL Young, MH Davies, SG Pollard \\ Leeds Teaching Hospitals NHS Trust, UK \\ *SG Wilson and AD White contributed equally to this work
}

ABSTRACT

INTRODUCTION Complications from HELLP (Haemolysis, Elevated Liver enzymes and Low Platelet) syndrome may present as an emergency to any surgeon. We review the ten-year experience of a tertiary hepatobiliary centre managing HELLP patients. Three selected cases are described to highlight our management strategy and a systematic review of the recent literature is presented.

METHODS All patients with HELLP syndrome were identified from a prospectively maintained database and their details collated. Subsequently, a detailed search of PubMed was carried out to identify all case series of HELLP syndrome in the literature in the English language since 1999.

RESULTS On review of 1,002 cases, 10 patients were identified with surgical complications of HELLP syndrome. Seven of these patients had a significant liver injury. Only three of these required surgical intervention for liver injury although four other patients required surgical intervention for other complications. There was no maternal mortality in this series. Review of the literature identified 49 cases in 31 publications. The management approaches of these patients were compared with ours. CONCLUSIONS We have presented a large series of patients with surgical complications resulting from HELLP syndrome managed without maternal mortality. This review has confirmed that haemodynamically stable patients with HELLP syndrome associated hepatic rupture can be conservatively treated successfully. However, in unstable patients, perihepatic packing and transfer to a specialist liver unit is recommended.

\section{KEYWORDS \\ Hepatopancreatobiliary - HELLP - Management - Surgery}

Accepted 25 January 2014

CORRESPONDENCE TO

Alastair Young, E: alyinbarbados@hotmail.com

The HELLP (Haemolysis, Elevated Liver enzymes and Low Platelet) syndrome was first described in $1982 .{ }^{1}$ It occurs in $0.17-0.85 \%$ of pregnancies and is more common among older, multiparous, Caucasian women. ${ }^{2}$ As its name suggests, it is characterised by haemolysis (diagnosed from a blood film), elevated liver enzymes (greater than 3 standard deviations above normal for the hospital) and a low platelet count $\left(<100 \times 10^{9} / \mathrm{l}\right) .^{3}$

The pathogenesis of HELLP syndrome is not completely understood and has been reviewed in detail elsewhere. ${ }^{4}$ Abnormal placental development can lead to increased oxidative stress as a result of ischaemia, similar to pre-eclampsia. This leads to the release of a variety of factors and cytokines, particularly products of abnormal metabolism of nitric oxide, prostaglandins and endothelin, which results in complement activation leading to endothelial dysfunction. This will then lead to platelet aggregation with consumption and, eventually, thrombocytopaenia. The haemolysis that occurs is microangiopathic, probably due to shearing stresses fragmenting red blood cells as they pass through small blood vessels with damaged intima and fibrin mesh deposits. ${ }^{5}$ This leads to microthrombi and fibrin deposition in the kidney, bringing about acute renal failure, and sinusoidal obstruction in the liver, disrupting hepatic blood flow and causing swelling, ischaemia and hepatic rupture.

Although rare, patients with HELLP syndrome may present as an emergency with complications of hepatic infarction, hepatic rupture with life threatening haemorrhage or other surgical complications associated with this condition. Despite being a condition managed primarily by obstetricians, if patients develop complications from HELLP, they invariably need to be managed by surgeons. In this paper, we review the ten-year experience of a single tertiary centre managing patients presenting with surgical complications as a result of HELLP. Three selected cases are reported as well as a systematic review of the recent literature on this subject to assess how our series compares with regard to presentation, management and outcomes.

\section{Methods}

A prospectively maintained database was reviewed of all patients managed in the liver unit of St James's University Hospital in Leeds. All patients with pregnancy associated 


\begin{tabular}{|c|c|c|c|c|c|c|c|}
\hline & $\begin{array}{l}\text { Age } \\
\text { (yrs) }\end{array}$ & Gestation & $\begin{array}{l}\text { Platelets } \\
\left(\times 10^{9} /\right)\end{array}$ & $\begin{array}{l}\text { ALT } \\
\text { (iu/l) }\end{array}$ & Operations & Complications & $\begin{array}{l}\text { Blood } \\
\text { transfused }\end{array}$ \\
\hline 1 & 38 & 29 wks (twins) & 70 & 271 & 4 laparotomies for liver rupture & Brain stem lesion & 30 units \\
\hline 2 & 34 & 34 wks & 43 & 324 & $\begin{array}{l}\text { Clinical observation and } \\
\text { monitoring }\end{array}$ & Subcapsular haematoma & 10 units \\
\hline 3 & 32 & 31 wks & 62 & 1,508 & Perihepatic packing (x3) & $\begin{array}{l}\text { Haemodialysis, laparostomy, } \\
\text { intraventricular bleed, pleural effusions }\end{array}$ & 45 units \\
\hline 4 & 39 & 28 wks & * & * & Thoracotomy, embolisation & $\begin{array}{l}\text { Haemothorax, Gl bleed, acute } \\
\text { renal failure }\end{array}$ & * \\
\hline 5 & 35 & 35 wks (twins) & 13 & 150 & $\begin{array}{l}\text { Clinical observation and } \\
\text { monitoring }\end{array}$ & $\begin{array}{l}\text { Haematemesis, ileus, encephalopathy, } \\
\text { liver haematomas }\end{array}$ & 4 units \\
\hline 6 & 20 & 36 wks & 38 & 45 & 2 laparotomies for liver rupture & Encephalopathy & 4 units \\
\hline 7 & 31 & 30 wks & 92 & 4,128 & $\begin{array}{l}\text { Perforated duodenal ulcer } \\
\text { repair }\end{array}$ & $\begin{array}{l}\text { Acute renal failure, respiratory failure, } \\
\text { liver haematoma }\end{array}$ & 3 units \\
\hline 8 & 32 & 35 wks & 97 & 200 & Right hemicolectomy & Ischaemic bowel, liver haematomas & 5 units \\
\hline 9 & 17 & 32 wks & 38 & 235 & Drainage of pelvic abscess & $\begin{array}{l}\text { Haemodialysis, ascites, splenomegaly, } \\
\text { multiple haemorrhagic liver lesions }\end{array}$ & Nil \\
\hline 10 & 30 & 34 wks (twins) & 30 & 133 & $\begin{array}{l}\text { Clinical observation and } \\
\text { monitoring }\end{array}$ & Haemodialysis, seizures, cellulitis & 3 units \\
\hline \multicolumn{8}{|c|}{$\begin{array}{l}\text { ALT = alanine transaminase; GI = gastrointestinal } \\
\text { * Laboratory results were not available as this patient was early in the series. Liver biopsy histology showed acute obliterative microangiopathy } \\
\text { and the discharge letter gave a diagnosis of HELLP syndrome owing to low platelets and elevated liver enzymes. }\end{array}$} \\
\hline
\end{tabular}

liver disease were identified by searching for the terms "pregnancy" or "pregnant". The database records all patient care episodes managed by the hepatology and liver transplant service at the hospital, which delivers quaternary level care in these specialties. Data recorded include patient demographics, diagnosis, test results and details of interventions (eg radiological or surgical). Patients' case notes were obtained and all patients with HELLP syndrome were evaluated retrospectively.

The definition of HELLP used was the presence of haemolysis (diagnosed from a blood film) associated with elevated liver enzymes (greater than 3 standard deviations above normal) and a low platelet count $\left(<100 \times 10^{9} / 1\right) .^{3}$ The patient's demographics, presentation, laboratory and imaging findings, and outcomes were assessed. This study was reviewed and approved by a departmental review board.

A detailed search of PubMed and MEDLINE ${ }^{\circledR}$ was carried out to identify all case series of HELLP syndrome in the literature in the English language since 1999. The last search was conducted on 31 January 2012. The following categories were combined using the Boolean term 'AND':

$>$ HELLP syndrome/therapy OR HELLP syndrome/complications OR HELLP syndrome/epidemiology OR HELLP syndrome/surgery

$>$ liver diseases/diagnosis OR liver diseases/etiology OR liver diseases/mortality

$>$ surgery OR laparotomy

$>$ injury OR injuries OR haemorrhage OR bleeding OR rupture OR complication OR complications

\section{Results}

A total of 1,002 patients were identified from the database. Of these, 962 were excluded as they were a duplicate entry, mentioned pregnancy as a risk while on post-transplant immunosuppression or were included owing to gallstone disease. Of the 40 cases remaining, 14 were due to cholestasis of pregnancy and 6 to acute fatty liver disease of pregnancy, 10 were confirmed cases due to HELLP syndrome and there were also 10 others.

The characteristics of the ten patients diagnosed with HELLP syndrome are shown in Table 1 . The median age at presentation was 32 years (range: 17-39 years). Three of the patients were pregnant with twins. Only two patients developed HELLP prior to their delivery with the remaining eight diagnosed following delivery. Seven patients had a significant liver injury and four of these were managed conservatively. Seven patients required surgical intervention; three of these were for liver rupture and four were for other complications of microangiopathy. The median blood transfusion was 4 units (range: 0-45) although all patients received multiple platelet transfusions. There was no maternal mortality in this series.

\section{Case 1}

A 38 year-old woman (Patient 1 in Table 1) who was 29 weeks pregnant with twins presented to a district general hospital with hypertension, proteinuria, right upper quadrant pain and vomiting. (Obstetric aspects of this case have been described previously. ${ }^{6}$ Liver function tests and platelet counts were normal but uric acid was raised. An 
emergency Caesarean section was performed owing to abnormal cardiotocography. One infant was delivered alive with the other stillborn. Approximately $200 \mathrm{ml}$ of fresh blood was found in a haemoperitoneum with no apparent cause. Intraoperative blood results showed a haemoglobin (Hb) level of $7.1 \mathrm{~g} / \mathrm{dl}$, a platelet count of $70 \times 10^{9} / \mathrm{l}$, an international normalised ratio of 1.0, an alkaline phosphatase level of $853 \mathrm{iu} / \mathrm{l}$ and an alanine transaminase (ALT) level of 271iu/l. She was transferred to the intensive care unit, and was transfused blood and platelets.

Increasing abdominal distension developed overnight and the patient became haemodynamically unstable. At relaparotomy, there was a tense haemoperitoneum secondary to bleeding from multiple hepatic tears and capsular disruption, and so the liver was packed. Postoperatively, she deteriorated and was transferred to the tertiary referral centre. Prior to transfer, she had received 20 units of blood as well as 16 units each of platelets, fresh frozen plasma and cryoprecipitate.

Following transfer to the tertiary centre, the patient underwent a further laparotomy by a consultant hepatobiliary/transplant surgeon. Access was difficult owing to obesity and a cruciate incision was employed. A tense haemoperitoneum was found with continued bleeding from multiple parenchymal tears. The liver was mobilised, bleeding was controlled by packing and a liver biopsy was taken.

Postoperatively, the patient required cardioversion and drainage of a pleural effusion. Following correction of the coagulopathy, she returned to theatre two days later and the packs were removed. There was good haemostasis and the wound was closed. She recovered well and was discharged after 35 days. Six months after discharge, she remained well.

\section{Case 2}

A 34-year-old primigravida woman (Patient 2 in Table 1) presented at 34 weeks with hypertension, proteinuria, platelets of $130 \times 10^{9} / \mathrm{l}$ and ALT of $36 \mathrm{iu} / \mathrm{l}$. Her blood pressure continued to rise despite intravenous labetalol, and she started vomiting and developed fundal tenderness. Cardiotocography was abnormal and so an emergency Caesarean section was performed. This was uneventful and a live infant was delivered. Platelets were $90 \times 10^{9} /$, ALT was 324iu/l and $\mathrm{Hb}$ was $12.2 \mathrm{~g} / \mathrm{dl}$.

The patient experienced shortness of breath four hours following surgery, and her platelet count and $\mathrm{Hb}$ level fell to $54 \times 10^{9} / \mathrm{l}$ and $6.5 \mathrm{~g} / \mathrm{dl}$ respectively. She became hypotensive, and developed abdominal distension and rightsided abdominal pain. Abdominal ultrasonography showed perihepatic fluid and computed tomography (CT) demonstrated a large subcapsular haematoma of the right lobe with ongoing bleeding. Three units of blood and one unit of platelets were transfused prior to transfer to the tertiary centre. There, magnetic resonance imaging (MRI) (Fig 1) showed a large subcapsular haematoma of the right lobe with oedema and free fluid in the abdomen but conservative management was continued. The patient received a further seven units of blood but made an uneventful recovery.

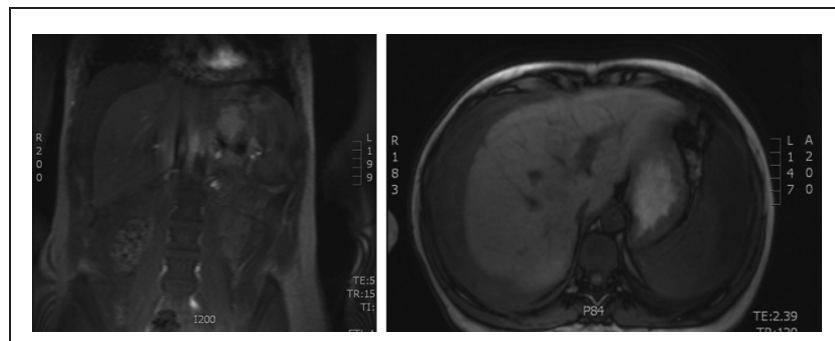

Figure 1 Magnetic resonance imaging showing a large subcapsular haematoma of the right lobe with oedema and free fluid in the abdomen

\section{Case 3}

A 32-year-old primigravida woman (Patient 3 in Table 1) was admitted at 31 weeks with epigastric and right upper quadrant pain. She had proteinuria and was hypertensive (228/115mmHg), which persisted despite best treatment. She deteriorated suddenly; her Glasgow coma scale score fell to 9 and repeat ultrasonography failed to identify a fetal heartbeat. Blood results demonstrated a platelet count of $62 \times 10^{9} / 1$ and an ALT of $1,508 i u / l$. HELLP was diagnosed and an emergency Caesarean section performed with delivery of a stillborn baby.

Two litres of blood were found in the peritoneal cavity secondary to liver rupture. The patient suffered a hypovolaemic cardiac arrest and the liver was packed. She received a total of 30 units of blood, 16 units of fresh frozen plasma, 8 units of platelets, 10 units of cryoprecipitate and 2 units of factor VIIa. She was transferred to a tertiary centre where she had several further pack changes in theatre and vacuum therapy to assist in wound closure. She required inotropic support, haemofiltration and ventilation for four weeks, and a further 15 units of blood. She was discharged after 64 days, having recovered completely.

\section{Discussion}

Abercrombie described the first case of spontaneous hepatic rupture in pregnancy in $1844 .^{7}$ In 1954 , Pritchard et al first described the association of haemolysis, elevated liver enzymes and thrombocytopaenia. ${ }^{8}$ The acronym HELLP was assigned by Weinstein in $1982 .{ }^{1}$

Cases of hepatic rupture in pregnancy are rare, with a reported incidence ranging from 1 in 45,000 to 1 in 225,000 deliveries, but it carries maternal mortality rates of $60-86 \%{ }^{9}$ The present case series is likely to have been subject to a degree of referral bias since patients who died rapidly or were unable to be transferred were excluded. However, zero maternal mortality in this series and the success of patients managed conservatively are important findings.

All published case reports or series subsequent to those reviewed in a previous paper by Reck $e t a l^{10}$ were analysed. We identified 34 cases in 16 publications describing hepatic rupture associated with HELLP syndrome (Appendix 1 available online only) $\cdot{ }^{11-26}$ Four patients $(12 \%)$ were treated 
conservatively, one of whom underwent radiologically guided percutaneous drainage of bloody ascitic fluid. Two case reports described incidences of hepatic rupture in association with HELLP that resulted in maternal death at admission.

Two patients underwent subsequent elective liver resection surgery, for intrahepatic haematoma and an atrophic left lobe due to recurrent cholangitis. Twenty-six patients underwent emergency surgery with eight requiring multiple laparotomies to manage the hepatic complications. A range of surgical techniques were employed including tamponade (perihepatic packing), suture ligation, fibrin gluing or a combination of the three. One patient received factor VIIa. Four patients required liver transplantation (one of whom required retransplantation).

\section{Presentation}

The most common findings in HELLP syndrome associated hepatic rupture are epigastric/right upper quadrant pain, hypotension, shock, nausea and vomiting, shoulder pain and headache. ${ }^{27,28}$ There is considerable variation in the presentation of hepatic rupture; signs and symptoms may be mild or completely absent until sudden circulatory collapse occurs. ${ }^{10,28}$ Hepatic rupture may occur prior to delivery, postpartum or during parturition. ${ }^{10,26}$ Consequently, a high index of clinical suspicion to the possibility of hepatic rupture is required when a patient with pre-eclampsia presents with upper abdominal pain. ${ }^{28}$

\section{Diagnosis}

While diagnostic, the triad signs of haemolysis, elevated liver enzymes (ALT and aspartate transaminase) and thrombocytopaenia are not invariably present from the outset, may be initially normal and could therefore be falsely reassuring. ${ }^{10}$ Elevated liver enzymes may reflect ongoing haemolysis as well as liver injury and the reduced platelet count is due to their increased consumption. ${ }^{29}$ Radiological imaging may aid with diagnosis.

Ultrasonography may be useful in identifying increased echogenicity of the liver. However, it is operator dependent and of limited value in detecting subtle intra-abdominal changes. ${ }^{28,29} \mathrm{CT}$ and MRI have both been described in the diagnosis of HELLP syndrome although imaging can only be used in stable patients. CT and MRI are also used for surveillance of postoperative patients as well as those managed conservatively.

In some cases, the diagnosis of liver rupture is made on finding a haemoperitoneum at the time of emergency Caesarean section.

\section{Management}

Early recognition of the gravity of the situation is likely to improve the outcome (Fig 2). In the first instance, the baby/ babies and placenta must be delivered as this removes the stimulus of the pathologies. The systemic microangiopathy of HELLP syndrome also affects systems other than the liver. In our series, surgical intervention was necessary for both infarcted bowel and infarcted lung. In addition, there are the potential complications of prolonged intensive care

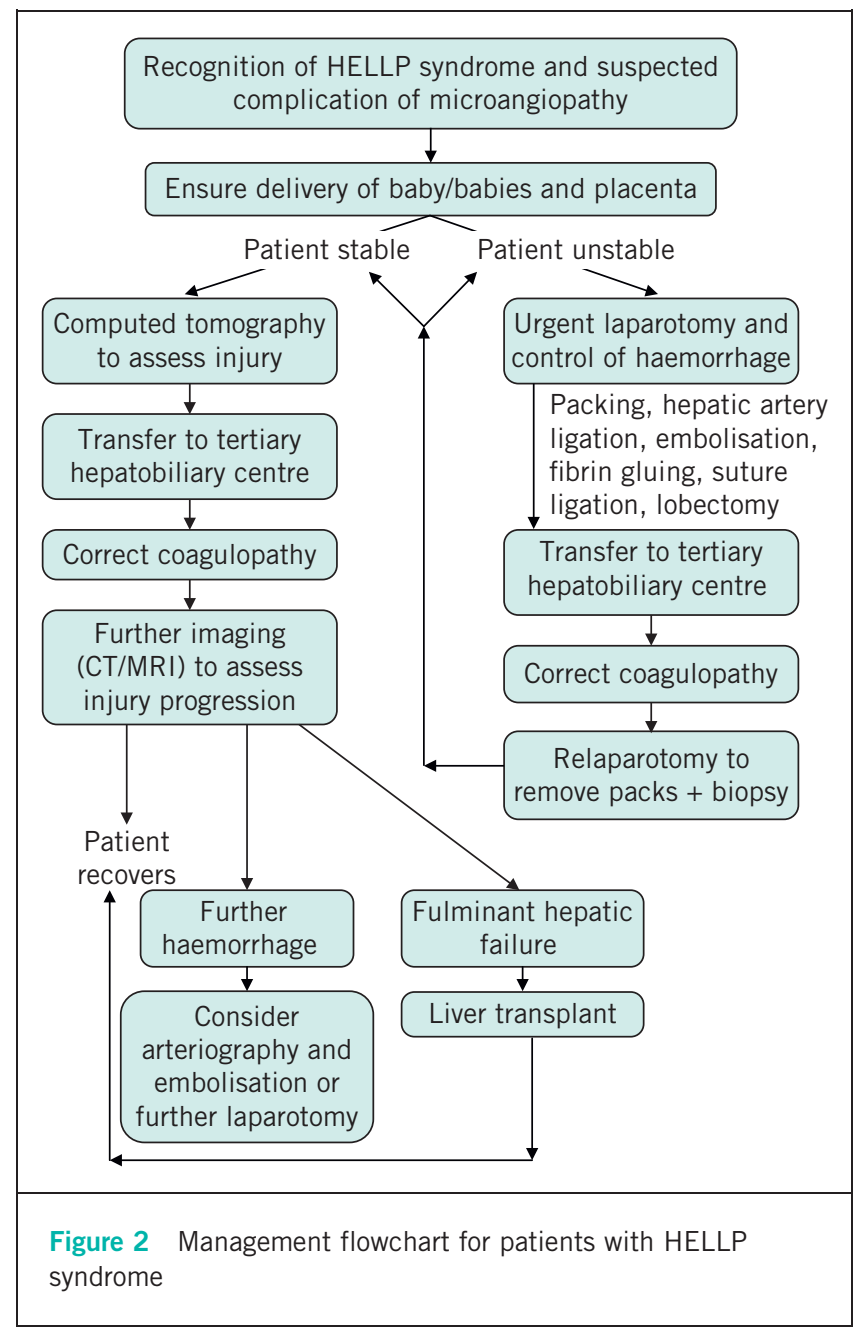

admissions, as demonstrated in this series with one patient who required repair of a perforated peptic ulcer.

There are eight reports in the literature of patients with hepatic rupture associated with HELLP syndrome who were successfully managed conservatively in addition to the six patients in our series. ${ }^{10,13,14,16}$ In all cases, the liver haematoma was small and/or contained, and patients underwent serial imaging (CT or ultrasonography) to monitor the haematoma. This should continue until the injury is considered stable or is resolving as hepatic rupture has been reported up to six weeks after initial presentation. ${ }^{15,28,30}$ In unstable patients, urgent laparotomy is recommended, which will likely necessitate packing followed by subsequent transfer to a specialist liver unit. ${ }^{10,15}$ Transfer should only be considered in unstable patients once control of the haemorrhage has been established, usually by packing, followed by temporary closure of the abdomen. ${ }^{10,15}$

Our approach has evolved following our widening experience of blunt liver trauma. ${ }^{31}$ Various techniques are described in the literature including perihepatic packing, fibrin gluing, hepatic artery ligation or embolisation, suture 
ligation of the damaged liver tissue, hepatic lobectomy and orthotic liver transplantation. ${ }^{10,28,32-37}$

For patients transferred after packing, following resuscitation with fluids and blood as well as correction of coagulopathy, a planned relaparotomy should be performed to remove or change packs and further management should be undertaken as appropriate. Liver biopsies may be required at this stage to assess parenchymal damage. ${ }^{10}$ In the event of refractory hepatic haemorrhage or progressive fulminant liver failure, a liver transplant should be considered. The decision to proceed to transplantation must be made early for the best chances of success. ${ }^{10,15,28}$ In extreme cases and where a suitable donor is not immediately available, a total hepatectomy with preservation of the inferior vena cava and a portocaval shunt may be considered until a donor organ becomes available. Such an anhepatic state can be survived for approximately 48 hours. ${ }^{10,28,36}$

\section{Conclusions}

HELLP syndrome is fortunately a rare condition but can present acutely in any hospital as a surgical emergency. We have presented a large series of patients with surgical complications resulting from HELLP managed without maternal mortality. The literature review has confirmed that haemodynamically stable patients with HELLP associated hepatic rupture can be conservatively treated successfully. However, in unstable patients, perihepatic packing and transfer to a specialist liver unit is recommended.

\section{References}

1. Weinstein L. Syndrome of hemolysis, elevated liver enzymes, and low platelet count: a severe consequence of hypertension in pregnancy. Am J Obstet Gynecol 1982; 142: 159-167.

2. Mihu D, Costin N, Mihu CM et al. HELLP syndrome - a multisystemic disorder. J Gastrointestin Liver Dis 2007; 16: 419-424.

3. Sibai BM. Diagnosis, controversies, and management of the syndrome of hemolysis, elevated liver enzymes, and low platelet count. Obstet Gynecol 2004; 103(5 Pt 1): 981-991.

4. Fang CJ, Richards A, Liszewski MK et al. Advances in understanding of pathogenesis of aHUS and HELLP. Br J Haematol 2008; 143: 336-348.

5. Reubinoff BE, Schenker JG. HELLP syndrome - a syndrome of hemolysis, elevated liver enzymes and low platelet count - complicating preeclampsiaeclampsia. Int J Gynaecol Obstet 1991; 36: 95-102.

6. Marsh FA, Kaufmann SJ, Bhabra K. Surviving hepatic rupture in pregnancy - a literature review with an illustrative case report. Obstet Gynaecol 2003; 23 109-113.

7. Abercrombie J. Hemorrhage of the liver. Lond Med Gaz 1844; 34: 792-794.

8. Pritchard JA, Weisman R, Ratnoff OD et al. Intravascular hemolysis, thrombocytopenia and other hematologic abnormalities associated with severe toxemia of pregnancy. N Eng/ J Med 1954; 250: 89-98.

9. Nelson EW, Archibald L, Albo D. Spontaneous hepatic rupture in pregnancy. Am J Surg 1977; 134: 817-820.

10. Reck T, Bussenius-Kammerer M, Ott R et al. Surgical treatment of HELLP syndrome-associated liver rupture - an update. Eur J Obstet Gynecol Reprod Biol 2001; 99: 57-65.

11. Yagmurdur MC, Agalar F, Daphan CE. Spontaneous hepatic rupture in pregnancy. Eur J Emerg Med 2000; 7: 75-76.

12. Mascarenhas R, Mathias J, Varadarajan R et al. Spontaneous hepatic rupture: a report of five cases. HPB 2002; 4: 167-170.
13. Carlson $\mathrm{KL}$, Bader $\mathrm{CL}$. Ruptured subcapsular liver hematoma in pregnancy: a case report of nonsurgical management. Am J Obstet Gynecol 2004; 190 558-560.

14. Wicke C, Pereira PL, Neeser E et al. Subcapsular liver hematoma in HELLP syndrome: evaluation of diagnostic and therapeutic options - a unicenter study Am J Obstet Gynecol 2004; 190: 106-112.

15. Shames BD, Fernandez LA, Sollinger HW et al. Liver transplantation for HELLP syndrome. Liver Transp/ 2005; 11: 224-228.

16. Araujo AC, Leao MD, Nobrega $\mathrm{MH}$ et al. Characteristics and treatment of hepatic rupture caused by HELLP syndrome. Am J Obstet Gynecol 2006; 195: 129-133.

17. Mindikoglu AL, Li SD, Yong SL et al. HELLP syndrome complicated bile duct injury and subsequent left hepatic lobe atrophy. Dig Dis Sci 2006; 51: $1,206-1,212$.

18. Dessole S, Capobianco G, Virdis P et al. Hepatic rupture after cesarean section in a patient with HELLP syndrome: a case report and review of the literature. Arch Gynecol Obstet 2007; 276: 189-192.

19. Sutton BC, Dunn ST, Landrum J, Mielke G. Fatal postpartum spontaneous live rupture: case report and literature review. J Forensic Sci 2008; 53: 472-475.

20. Pavlis T, Aloizos S, Aravosita $\mathrm{P}$ et al. Diagnosis and surgical management of spontaneous hepatic rupture associated with HELLP syndrome. J Surg Educ 2009; 66: 163-167.

21. Kelly J, Ryan DJ, O'Brien N, Kirwan W. Second trimester hepatic rupture in 35 year old nulliparous woman with HELLP syndrome: a case report. World J Emerg Surg 2009; 4: 23.

22. Connor K, Rubin RA, Shrestha $R$ et al. ABO incompatible liver transplantation as a bridge to treat HELLP syndrome. Gastroenterol Res Pract 2009; 713937.

23. Miguelote RF, Costa V, Vivas J et al. Postpartum spontaneous rupture of a liver hematoma associated with preeclampsia and HELLP syndrome. Arch Gynecol Obstet 2009; 279: 923-926.

24. Varotti G, Andorno E, Valente U. Liver transplantation for spontaneous hepatic rupture associated with HELLP syndrome. Int J Gynaecol Obstet 2010; 111: 84-85.

25. Chou PY, Yu CH, Chen CC, Chen WT. Spontaneously ruptured subcapsular liver hematoma associated with hemolysis, elevated liver enzymes and low platelets (HELLP) syndrome. Taiwan J Obstet Gynecol 2010; 49: 214-217.

26. Gutiérrez-Cafranga E, García-Molina FJ, León-del-Pino R et al. Hepatic rupture and hemoperitoneum in a pregnant woman with HELLP syndrome. Rev Esp Enferm Dig 2010; 102: 453-454

27. Rinehart BK, Terrone DA, Magann EF et al. Preeclampsia-associated hepatic hemorrhage and rupture: mode of management related to maternal and perinatal outcome. Obstet Gynecol Surv 1999; 54: 196-202.

28. Marsh FA, Kaufmann SJ, Bhabra K. Surviving hepatic rupture in pregnancy - a literature review with an illustrative case report. J Obstet Gynaecol 2003; 23: 109-113.

29. Haram K, Svendsen E, Abildgaard U. The HELLP syndrome: clinical issues and management. A review. BMC Pregnancy Childbirth 2009; 9: 8.

30. Sheikh RA, Yasmeen S, Pauly MP, Riegler JL. Spontaneous intrahepatic hemorrhage and hepatic rupture in the HELLP syndrome: four cases and review. J Clin Gastroenterol 1999; 28: 323-328.

31. Coughlin PA, Stringer MD, Lodge JP et al. Management of blunt liver trauma in a tertiary referral centre. Br J Surg 2004; 91: 317-321.

32. Bis KA, Waxman B. Rupture of the liver associated with pregnancy: a review of the literature and report of 2 cases. Obstet Gynecol Surv 1976; 31: 763-773.

33. Loevinger EH, Vujic I, Lee WM, Anderson MC. Hepatic rupture associated with pregnancy: treatment with transcatheter embolotherapy. Obstet Gynecol 1985; 65: 281-284

34. Neerhof MG, Zelman W, Sullivan T. Hepatic rupture in pregnancy. Obstet Gynecol Surv 1989; 44: 407-409.

35. Nelson DB, Dearmon V, Nelson MD. Spontaneous rupture of the liver during pregnancy: a case report. J Obstet Gynecol Neonatal Nurs 1989; 18: 106-113.

36. Pachter HL, Spencer FC, Hofstetter SR et al. Significant trends in the treatment of hepatic trauma. Experience with 411 injuries. Ann Surg 1992; 215 492-500.

37. Hunter SK, Martin M, Benda JA, Zlatnik FJ. Liver transplant after massive spontaneous hepatic rupture in pregnancy complicated by preeclampsia. Obstet Gynecol 1995; 85(5 Pt 2): 819-822. 
Appendix 1 Summary of 34 case reports in 16 publications describing hepatic rupture associated with HELLP syndrome

\begin{tabular}{|c|c|c|c|c|c|c|c|c|c|c|}
\hline Authors & $\begin{array}{l}\text { Age } \\
\text { (yrs) }\end{array}$ & Gestation & Parity & CS? & $\begin{array}{l}\text { Platelets } \\
\left(\times 10^{9} / \mathrm{l}\right)\end{array}$ & $\begin{array}{l}\text { ALT } \\
\text { (iu/l) }\end{array}$ & $\begin{array}{l}\text { LDH } \\
\text { (iu/l) }\end{array}$ & $\begin{array}{l}\text { Treatment / } \\
\text { operative } \\
\text { technique }\end{array}$ & $\begin{array}{l}\text { Maternal } \\
\text { death? }\end{array}$ & $\begin{array}{l}\text { Cause of } \\
\text { death }\end{array}$ \\
\hline $\begin{array}{l}\text { Yagmurdur, } \\
2000^{11}\end{array}$ & 38 & 24 wks & ++ & $\mathrm{N}$ & & 598 & & $\begin{array}{l}\text { Laparotomy, } \\
\text { hysterotomy }\end{array}$ & $\mathrm{N}$ & \\
\hline \multirow[t]{3}{*}{$\begin{array}{l}\text { Mascarenhas, } \\
2002^{12}\end{array}$} & 26 & 38 wks & 0 & Y & 325 & 69 & & $\begin{array}{l}\text { Elective right } \\
\text { hepatectomy }\end{array}$ & $\mathrm{N}$ & \\
\hline & 28 & 38 wks & 0 & Y & 64 & 109 & & $\begin{array}{l}\text { Perihepatic } \\
\text { packing }(\times 2) \text {, } \\
\text { splenectomy }\end{array}$ & $\mathrm{N}$ & \\
\hline & 30 & 30 wks & 0 & $\begin{array}{l}\text { Y } \\
\text { (stillborn) }\end{array}$ & 40 & 516 & & $\begin{array}{l}\text { Perihepatic } \\
\text { packing }\end{array}$ & $\mathrm{N}$ & \\
\hline $\begin{array}{l}\text { Carlson, } \\
2003^{13}\end{array}$ & 27 & 34 wks & 0 & Y & 80 & 258 & & $\begin{array}{l}\text { Clinical } \\
\text { observation } \\
\text { and monitoring }\end{array}$ & $\mathrm{N}$ & \\
\hline \multirow[t]{5}{*}{$\begin{array}{l}\text { Wicke, } \\
2004^{14}\end{array}$} & 33 & 37 wks & 2 & Y & 33 & 116 & 383 & $\begin{array}{l}\text { Clinical } \\
\text { observation } \\
\text { and monitoring }\end{array}$ & $\mathrm{N}$ & \\
\hline & 26 & 36 wks & 0 & Y & 143 & 573 & 632 & $\begin{array}{l}\text { Clinical } \\
\text { observation and } \\
\text { monitoring }\end{array}$ & $\mathrm{N}$ & \\
\hline & 26 & 22 wks & 0 & $\begin{array}{l}\text { N (induced, } \\
\text { stillborn) }\end{array}$ & 35 & & & $\begin{array}{l}\text { Percutaneous } \\
\text { drainage, ascites }\end{array}$ & $\mathrm{N}$ & \\
\hline & 30 & 40 wks & 0 & Y & 25 & 990 & & $\begin{array}{l}\text { Repeated perihepatic } \\
\text { packing }\end{array}$ & $N$ & \\
\hline & 29 & 34 wks & 0 & Y & 44 & 730 & & $\begin{array}{l}\text { Laparotomy, } \\
\text { hysterectomy, } \\
\text { progressive liver } \\
\text { damage / complete } \\
\text { parenchymal } \\
\text { destruction, LTx }\end{array}$ & $\mathrm{N}$ & \\
\hline $\begin{array}{l}\text { Shames, } \\
2005^{15}\end{array}$ & 37 & 35 wks & 4 & $\begin{array}{l}\mathrm{N} \\
(\mathrm{NVD})\end{array}$ & 55 & +++ & & $\begin{array}{l}\text { Perihepatic } \\
\text { packing. } \\
\text { Developed } \\
\text { coagulopathy, } \\
\text { abdominal } \\
\text { compartment } \\
\text { syndrome, cardiac } \\
\text { arrest, OLTx. }\end{array}$ & $\mathrm{N}$ & \\
\hline \multirow[t]{7}{*}{$\begin{array}{l}\text { Araujo, } \\
2006^{16}\end{array}$} & 36 & 36 wks & 2 & & 92.0 & 1,861 & 1,514 & $\begin{array}{l}\text { Hepatic artery } \\
\text { ligation, } \\
\text { cholecystectomy }\end{array}$ & $\mathrm{N}$ & \\
\hline & 44 & Postpartum & 14 & & & & & & Y & $\begin{array}{l}\text { Dead at } \\
\text { admission }\end{array}$ \\
\hline & 43 & 24 wks & 10 & & & & & Omental patching & $\mathrm{N}$ & \\
\hline & 48 & Postpartum & 3 & & & & & Suture ligation & $\mathrm{N}$ & \\
\hline & 43 & 37 wks & 15 & & & & & $\begin{array}{l}\text { Hepatic artery } \\
\text { ligation, omental } \\
\text { patching }\end{array}$ & $\mathrm{N}$ & \\
\hline & 42 & 34 wks & 5 & & & & & $\begin{array}{l}\text { Hepatic artery } \\
\text { ligation, omental } \\
\text { patching }\end{array}$ & $\mathrm{N}$ & \\
\hline & 45 & 40 wks & 15 & & & & & $\begin{array}{l}\text { Suture ligation, } \\
\text { omental patching }\end{array}$ & $\mathrm{N}$ & \\
\hline
\end{tabular}


Appendix 1 Summary of 34 case reports in 16 publications describing hepatic rupture associated with HELLP syndrome (Continued)

\begin{tabular}{|c|c|c|c|c|c|c|c|c|c|c|}
\hline Authors & $\begin{array}{l}\text { Age } \\
\text { (yrs) }\end{array}$ & Gestation & Parity & CS? & $\begin{array}{l}\text { Platelets } \\
\left(\times 10^{9} / \mathrm{I}\right)\end{array}$ & $\begin{array}{l}\text { ALT } \\
\text { (iu/l) }\end{array}$ & $\begin{array}{l}\text { LDH } \\
\text { (iu/l) }\end{array}$ & $\begin{array}{l}\text { Treatment / } \\
\text { operative } \\
\text { technique }\end{array}$ & $\begin{array}{l}\text { Maternal } \\
\text { death? }\end{array}$ & $\begin{array}{l}\text { Cause of } \\
\text { death }\end{array}$ \\
\hline & 42 & 35 wks & 3 & & & & & $\begin{array}{l}\text { Hepatic artery } \\
\text { ligation, omental } \\
\text { patching }\end{array}$ & $\mathrm{N}$ & \\
\hline & 38 & 38 wks & 4 & Y & 91.4 & 768 & 2,207 & $\begin{array}{l}\text { Clinical } \\
\text { observation and } \\
\text { monitoring }\end{array}$ & N & \\
\hline & 27 & 33 wks & 3 & & & & & $\begin{array}{l}\text { Hepatic artery } \\
\text { ligation, } \\
\text { cholecystectomy }\end{array}$ & $\mathrm{N}$ & \\
\hline $\begin{array}{l}\text { Mindikoglu, } \\
2006^{17}\end{array}$ & 25 & $\begin{array}{l}\text { Day } 4 \\
\text { postpartum }\end{array}$ & & N & 48 & 166 & 475 & $\begin{array}{l}\text { Conservative } \\
\text { management. } \\
\text { Recurrent } \\
\text { cholangitis } 13 \text { yrs } \\
\text { later, atrophic left } \\
\text { lobe, dilated CBD, } \\
\text { left lobectomy. }\end{array}$ & N & \\
\hline $\begin{array}{l}\text { Dessole, } \\
2007^{18}\end{array}$ & 35 & 38 wks & 0 & Y & 95 & 163 & & $\begin{array}{l}\text { Perihepatic } \\
\text { packing }(\times 3)\end{array}$ & N & \\
\hline $\begin{array}{l}\text { Sutton, } \\
2008^{19}\end{array}$ & 25 & 30 wks & 3 & Y & & & & & Y & $\begin{array}{l}\text { Dead at } \\
\text { admission } \\
\text { owing to hep- } \\
\text { atic rupture / } \\
\text { haemorrhagic } \\
\text { shock }\end{array}$ \\
\hline \multirow[t]{3}{*}{$\begin{array}{l}\text { Pavlis, } \\
2009^{20}\end{array}$} & 38 & $\begin{array}{l}38 \text { wks } \\
\text { (twins) }\end{array}$ & & Y & 20 & 2,500 & & $\begin{array}{l}\text { Perihepatic } \\
\text { packing }(\times 2) \text {, } \\
\text { suture ligation }\end{array}$ & N & \\
\hline & 38 & 37 wks & & Y & 50 & 2,000 & & $\begin{array}{l}\text { Perihepatic } \\
\text { packing }(\times 2) \text {, } \\
\text { suture ligation, } \\
\text { argon laser }\end{array}$ & N & \\
\hline & 32 & 40 wks & & $\mathrm{N}$ & 53 & 1,752 & & $\begin{array}{l}\text { Perihepatic } \\
\text { packing, factor } \\
\text { VIlla }\end{array}$ & N & \\
\hline $\begin{array}{l}\text { Kelly, } \\
2009^{21}\end{array}$ & 35 & $\begin{array}{l}18 \text { wks } \\
\text { (IVF) }\end{array}$ & 0 & & 105 & 2,823 & 14,361 & $\begin{array}{l}\text { Perihepatic packing, } \\
\text { hysterotomy }\end{array}$ & $\mathrm{N}$ & \\
\hline $\begin{array}{l}\text { Connor, } \\
2009^{22}\end{array}$ & 28 & 37 wks & 1 & Y & 39 & 1,319 & 2,215 & $\begin{array}{l}\text { Initial OLTX (ABO } \\
\text { incompatible), graft } \\
\text { failure, } \\
\text { re-LTx }\end{array}$ & $\mathrm{N}$ & \\
\hline $\begin{array}{l}\text { Miguelote, } \\
2009^{23}\end{array}$ & 28 & 36 wks & 0 & Y & & & & $\begin{array}{l}\text { Perihepatic } \\
\text { packing }(\times 3)\end{array}$ & N & \\
\hline $\begin{array}{l}\text { Varotti, } \\
2010^{24}\end{array}$ & 43 & 38 wks & 2 & Y & 55 & 822 & 2,220 & $\begin{array}{l}\text { Total hepatectomy, } \\
\text { temporary portocaval } \\
\text { shunt, OLTx }\end{array}$ & $\mathrm{N}$ & \\
\hline $\begin{array}{l}\text { Chou, } \\
2010^{25}\end{array}$ & 33 & 26 wks & 2 & Y & 153 & 315 & 652 & Perihepatic packing & $\mathrm{N}$ & \\
\hline $\begin{array}{l}\text { Gutiérrez- } \\
\text { Cafranga, } \\
2010^{26}\end{array}$ & 25 & 39 wks & & Y & 17 & 1,060 & 1,941 & Perihepatic packing & $\mathrm{N}$ & \\
\hline
\end{tabular}

